Received September 15, 2011

Revised November 2, 2011

Accepted November 30, 2011

\title{
Technology Policy in Developing Countries: Indigenous Programs and Political Economy Theory
}

\author{
JOEl R. CAMPBElL
}

The nature of the state and whether it is able to create a national innovation system have been the primary variables determining the direction of technology policy. This article considers five major cases: Taiwan and Korea, India, China, and Tanzania. Two of the cases, Taiwan and Korea, represent Newly Industrializing Economies, while India and China represent emerging continental economies. All four have been, to varying degrees, successful instances. Taiwan and Korea were able to link industrial development with applied technology development, while China and India had mixed successes and took much longer to realize technology policy goals. Tanzania illustrates the difficulties encountered by developing countries in creating a science and technology infrastructure. The article also presents theoretical implications of these cases, and assesses shortcomings in technology policy literature.

Keywords: Science and Technology, Developmental State, Policy Process

\footnotetext{
- Associate Professor, Troy University: E-mail: joeljapan2@hotmail.com
} 


\section{INTRODUCTION}

$\mathrm{T}$

he nature of the state and whether it is able to create a national innovation system have been the primary variables determining the direction of technology policy. This article considers five major cases: Taiwan and Korea, India, China, and Tanzania. Taiwan and Korea were considered successes because of their ability to link industrial development with applied technological eftorts, India had mixed success, while China was successful in creating a broad-based technology infrastructure, though it took nearly thirty years to do so. Tanzania represents the less successful efforts within the developing world, with vast ambitions that were never realized because of lack of resources and international support. The article also highlights several shortcomings of current technology policy literature for the developing world.

This study employs a case study approach to illustrate the nature of technology policy outcomes in developing countries. It examines technological innovation through the creation of a national innovation system, and the political and economic institutions or processes involved in science and technology policymaking. It also considers the methods by which science and technological knowledge and know-how are acquired. Case studies illustrate the ways in which the policy process focuses on political and economic goals. It shows why policy makers make the decisions that they do, why they select particular policy options, why they select particular options over others, and assess relative gains and losses of particular policies (Carter: 5-7). Each case presents background, key developments, and a conclusion indicating what can be learned from that case. Two of the cases, Taiwan and Korea, represent Newly Industrializing Economies (NICs), while India and China represent emerging continental economies. All four have been relatively successful cases, while Tanzania illustrates the difficulties encountered by developing countries in creating a science and technology (S\&T) infrastructure.

Scholars of technology development divide into at least four camps: (1) statists such as Tuma and Hveem, who see autonomous states playing the lead role in technology development (Tuma 1987; James and Khan 1998), (2) dependency theorists such as Philippart and Greven, who think the cards are stacked against either useful transfer or effective indigenous development (Philippart 1982; Greven 1982; Freeman and Soete 1999), (3) "bargaining" theorists such as Grieco and Adler (see India below), who see opportunities for developing countries to exploit world markets to gain needed technology, while building domestic coalitions in favor of particular indigenous projects, and (4) mixed approaches such as that of Williams, who see elements of both state efficacy and dependency at work in technology policy (Williams 1984). Statists have developed the most coherent theoretical approaches, while others have contributed important insights to literature on technology policy in the developing world.

Technology is one of the driving forces of modern economic development, 
and the twentiech century perhaps was the first time in history that technological concerns came to dominate people's lives. At the beginning of that century, the machine age was widely celebrated, but over 100 years later it is seen as a distinctly mixed blessing. Many of the problems connected with technology relate to mass usage of machines, such as environmental pollution, societal breakdown, and dependence of developing nations on the advanced countries (Kegley and Wittkopf 1997; Papp 1997; Rosenberg 1994).

Technology also is a significant force in national and international affairs. It has helped make the world more market interdependent, and has allowed instantaneous communications. It has "caused a rapidly shrinking world" where the affairs of separate states become "interlaced," and has become one of the main drivers of globalization (Padelford et al. 1976; Clemens 2004). Since K. $\mathrm{J}$. Holsti, international relations scholars list a nation's level of technology, along with military capability and international reputation, as a criterion for differentiating states in the international system. Wherever modern technology takes root, it tends to be cumulative, accelerative, irreversible, and widely diffused. It has forced a redefinition of the traditional bases of foreign policy, undermined state control of information, and downgraded the importance of geographic distance, national size, population, and location. Technological advancement becomes a necessity for great powers, and possession of key technologies materially affects the conduct of foreign policy (Holsti 1972).

Despite the mixed blessings of technology, developing countries still see it as the key to economic development. Policymakers in the developing world often believe that, since it often can be easily adapted by even backward countries, technology can be used to skip traditional stages of economic development. The spread of advanced technology is uneven, but technology development has been a key factor behind common patterns of development, that is, the rise of an industrial sector, increasing interdependence of countries, declining agricultural self-sufficiency due to increased urbanization, and heightened competition for scarce resources (Holsti 1972). Technology is thus an integral element of the developmental process.

It is clear from the paucity and heterogeneity of literature on indigenous programs that more work needs to be done in this field, and there is an absence of adequate indicators. Those suggested by Morita-Lou may serve as general guides, but research requires more specific ones (see discussion below for more on her suggested indicators). What is needed is a more focused examination at technological upgrading based on major techno-economic shifts.

\section{TECHNOLOGY DEVELOPMENT IN DEVELOPING COUNTRIES: KEY CASES}

Developing countries in the postwar era have focused on key industries. Such 
industries differ by country, according to policy choices made initially be political leadership, and then selected by the private sector. In East Asia, these generally have centered on electronics, computers, biotechnology, and "strategic industries," that is, technological areas deemed of vital strategic/military or political economic value by the state. Rowen et al. note that East Asia succeeded technologically by seizing opportunities in expanding world markets. These included reductions in trade barriers, falling transportation and telccommunications costs, the growth of the information technology (IT) industry, which includes telecommunications, the modularization of technology standards, and a growing division of labor (large developed countries as initial innovators and markets, Asian companies as major producers). All this has gradually put manufacturing abilities of Japanese (and more recently, Taiwanese and Korean) companies at the center of the IT industry. National strategies have focused on technical education, acquisition and development of new technologies, facilitation of trade and foreign direct investment, government fostering of industries through control of finance, and creation of high technology regional clusters (Rowen 2007).

\section{Soutb Korea and Taiuan}

Rower's thesis can be easily seen in two leading East Asian Newly Industrialized Countries. If Japan has been the premier technology developer of the postwar era, the East Asian NICs have been her most eager students. Shih, Wang, and Wei point out the key roles played by the government, from the creation of the Hsinchu Science-based Industrial Park (HSIP) as a key incubator for companies spun off from the state-run Industrial Technology Research Institute (ITRI), to the fostering of venture capital from the 1980s, to encouragement of corporate innovation in the 1990s (Shih et al. 2007). Taiwan has shifted from light industrial manufacturing to high technology industries, and focused on electronics and information technology from the late 1980s onward. In the first thirty years of Kuomintang rule, the state played a critical role fostering key economic sectors, and during the 1980 s helped to remove obstacles to development of Taiwan's leading firms. The nation's various economic plans, such as the ninth medium term plan (1986-1989), identified key areas of commercial technology that the nation's enterprises should develop, including automation, information technology, biotechnology, and software services. Taiwanese companies focused on original equipment manufacturing (OEM) until they were able to build their own brands (Berger and Lester 2005). Taiwanese technology development got a strong boost from state involvement in four areas: (1) help to local firms in making relationships with MNCs, (2) designation of ITRI as the lead technology development organization, designed in part to spin-off promising ventures, (3) emphasis on manufacturing over technology development, and (4) promotion of Taiwan firms as suppliers for leading MNCs. The state also established 
the S\&T-oriented HSIP, southwest of Taipei, as a venue to link research and production and a lure for the return of many expatriate scientists from the United States (Fuller 2005).

By contrast, South Korea has tried to build a "National Innovation System" similar to those of the developed nations, built on the three pillars of state research organizations, corporate $R \& D$, and university research laboratories. Bae et al. note that much of Korea's development has centered on two technology clusters or "valleys," that is, Daedeok and Teheran. Daedeok began as a venue for relocating research institutes from Seoul, but from the 1990s began to develop as enough researchers became present to start their own companies. Teheran was started as a private initiative, and focused almost exclusively on software and content for technology devices (Zong 2007). Korea's technology development can be divided into three periods: (1) creation of basic institutions and imitative technology efforts during the 1960s-1970s, (2) establishment of large firm R\&D capacity during the 1980s to early 1990s, and (3) branching into basic research since the mid-1990s. During the first period, the state in the form of large research organizations dominated technology development, whereas the large chaebols (conglomerates) took the lead during the second. During the more recent period, small firms and universities have emerged as important players alongside the large corporate actors, small and medium-sized enterprises (SMEs) are attracting more skilled personnel, and the creation of technology transfer offices in universities has fostered greater university-industry R\&D cooperation. The percent of $R \& D$ activities conducted by the private sector is now the largest among OECD countries. Korean firms such as Samsung Electronics have emerged as major international competitors. State efforts remain relatively weak, in part because of fragmented authority and spending among six major ministries and other organizations (Hemmert 2007).

Arnold states that Taiwan and South Korea have followed similar developmental strategies, and have concentrated on building organizations and institutions as a way to foster indigenous S\&T capability. Taiwan's industrial technology was stimulated by a combination of factors, notably extensive U.S. aid until 1965 and an influx of foreign investment with technology transfers. Taiwan relied on importation of technology to a great extent, and the state used a decentralized approach with weak central coordination. Since the early 1970s, though, Taipei encouraged indigenous industrial and commercial technology, while still relying on MNCs for technology imports (Arnold 1989).

Arnold says South Korea built an S\&T structure relatively more independent of foreign technology. The Ministry of Science and Technology (MOST) was much more powerful than Taiwan's comparable National Science Council (NSC), and directed centralized development of an indigenous capability. Korea's S\&T policy since the early 1960 s was to develop its economy with minimal foreign direct investment, and it was able to do so in part because of heavy U.S. and 
Japanese aid. To offset the lack of foreign direct investment and absence of MNCs, the government took the lead role in technology development. At first, the government strictly controlled technology imports, but gradually allowed greater "sourcing" of technology from MNCs. This shift was in part due to Korea's huge foreign debt, which may have forced the government to reconsider direct foreign investment. It was also a way to reduce reliance on domestic firms for S\&T advances (Arnold 1989).

Chudnovsky and Nagao describe the entry of South Korea and Brazil into indigenous design and manufacture of capital goods. In Korea, capital goods production increased fifteen-fold from the early 1960s to mid-1980s, and serviced over sixty percent of Korean capital goods needs. Capital goods imports were favored in the 1960s and early 1970s through tariff exemptions, overvaluation of the won, supplier credits, and so on. After 1973, the government shifted to control of imports, allowing exemptions from tariffs only for essential equipment. Indigenous manufacture of capital goods was promoted by medium and long-term credits and quotas on competing imports. Unlike Brazil and India, Korea's capital goods industry was from the beginning an exporter. encouraged by subsidies and credit preferences. The government also encouraged creation of several major research institutes to support the industry (Chudnovsky and Nagato 1984; Edwards 1992).

Like Arnold, Choi emphasizes the role of government planning in South Korean technology development. Particularly, the First through Third Five-Year Plans during the $1960 \mathrm{~s}$ and $1970 \mathrm{~s}$ guided acquisition and exploitation of different kinds of technology at each stage of development. The first plan called for building infrastructure industries and evolution of light industry, the second pushed heavy industrialization and capital intensive projects, and the third attempted to bring better economies of scale and introduce high tech industrialization. At the same time, the government funded three industrial research institutes and an information clearing house (Choi 1986).

Like Korea, Chudnovsky and Nagao show Brazil early-on allowed capital goods imports, but began to cut them back in 1974. The government tried to promote an indigenous capital goods industry through non-tariff barriers to equipment imports, incentives to encourage a high proportion of Brazilian equipment in local projects, and provision of fiscal and financial assistance to Brazilian makers of capital equipment. Nevertheless, unlike Korea, the government did not discourage direct investment by MNCs (Choi 1986).

\section{India}

Since independence in 1947, India has built a vast, multi-level technology structure (Malhotra and Patel 2003). At its core are several central government departments which promote various S\&T programs; for instance, the Ministry 
of Science and Technology has promoted basic research, while the Department of Science and Technology has focused more on industrial technology. The government has created over 800 research institutions, including 400 national laboratories and 200 university research facilities. Roughly 1,300 firms now have in-house R\&D facilities (United Nations). The government has also promoted technology transfer throughout since the 1950s (Gupta and Reisman). During the 1990s, partiy as a resuit of the economic liberalization begun in 1991 , both corporate and government research made a major push into IT. Dossani notes that India's greatest recent success has been the creation of the software industry, almost entirely by the private sector. Private software companies began operating under adverse conditions in the 1970 s, found ways to exploit the first reforms in the 1980 s, and then prospered during the post-1991 liberalization. The industry has successfully leveraged its advantages, such as outsourcing and clustering (most notably in Bangalore) (Dossani 2007).

Like Japan and the NICs, says Desai, market forces have shaped the direction of Indian technology. Where the market helped the NICs, before 1991 it led to stagnation of Indian efforts and ensured that they remained puny. Most Indian companies were small to start with, and because of keen competition, were often unwilling to invest in long-term S\&T projects. The few existing large firms were averse to taking on added risks associated with S\&T because of strong licensing and anti-monopoly laws. Also, few foreign firms initially wished to invest heavily in India because of chronic low growth (at least until the 1990s). Finally, a competitive market structure that forced technology suppliers to sell cheaply and early to realize profits can lead to "disconnected imports of each successive vintage as well as its imperfect absorption" (Desai 1988).

Unlike the NICs, say Chudnovsky and Nagao, India followed a heavy industrialization program that was closer to the Five-Year Plans of the Soviet Union. From the beginning, the government set a goal of self-sufficiency in the capital goods industry and assigned indigenous manufacture of machine tools and electrical equipment to specific companies. This essentially import-substituting policy was fostered by protectionism and control of foreign technology imports. As a result, India was able to supply over eighty percent of its capital goods needs in the 1980s (Desai 1988).

Development of the Indian petrochemical industry, as sketched by Khanna, is another example of the Indian search for self-sufficiency. In the early 1960s, the Indian government put together a plan with cooperation of the French Petroleum Institute, calling for construction of five major petrochemical complexes by the early $1970 \mathrm{~s}$. The plan divided the industry into two sectors. Class A included bulk chemicals such as ethylene, propylene, benzene, and intermediate chemicals such as acetone and phenol, whose chemical properties were well established and so could be easily produced. These would be produced by 100 percent Indian-owned firms. Class B included intermediates and finished products 
whose properties were determined by end use, the know-how for which was determined by the laboratories of large MNCs. These would be produced by MNCs entirely or by joint ventures. Relations with the MNCs were generally not good, and the government came to feel it should control the projects under development.

The MNCs did cooperate in transferring technology, but most of it was "totally packaged" and almost entirely handled by the MNCs or their subsidiaries. Technology thus acquired was fairly expensive, coming to an average of cwenty percent of the cost of projects, and there were various restrictive provisions attached to the transfers, such as no export rights or sub-licensing. Some of the MNCs also insisted on rights to process and market products produced with the technology. After the plants were set up, MNCs continued to exercise control over the technology through expatriate personnel and "technical service agreements" that included knowledge necessary for even routine plant operations. Only one of the complexes had an R\&D facility and made plans for expansion of the indigenous industry, but little was done to implement these plans. Furthermore, Khanna suggests, Indian efforts to develop a petrochemical industry were hobbled by a lack of government funding and "attempt[ing] to do too much in a very weak market" (Khanna 1984).

India has fared much better in building a computer industry, says Grieco, by managing its relationships with MNCs. In the 1960s, the government's computer strategy was geared to military applications and development of a small number of producers of large systems. This early strategy was not successful because there was not a ready market for large computers, because the government promoted Electronics Corporation of India, Led. (ECIL) as a national champion to the exclusion of other companies, and because the government had little success negotiating with MNCs. However, in the 1970s, the government shifted strategy toward production of personal computers, better funding for ECIL's operations, and allowing greater competition among a variety of firms. This switch was spurred by the success of India's Atomic Energy Commission's "network" in gradually taking over the formulation of computer policy from the Defence Ministry. The Indian computer industry was also able to form more effective links with computer MNCs in the late 1970s than before. These included export processing zones and joint ventures (Grieco 1982).

Grieco sees the Indian success in negotiating with computer MNCs as an indication that the "bargaining" approach provides a better explanation of Indian development than the "Marxist-dependencia" approach. According to the bargaining school, the terms under which a firm operates in a country, as well as the distribution of benefits from the operation, are determined by negotiations and the balance of power between an MNC and a host country. Next, the balance of power and relative assets in a developing industry-capital, technology, and expertise-often initially favors the MNC. However, the host country over 
time gains access to the sources of power originally controlled by the MNCs. Grieco's study leads him to conclude that international innovations and changes in the structure of the international computer market gave the MNCs greater power than their Indian counterparts, but that Indian negotiators were nonetheless able to exploit these changes to improve their relations with the MNCs. This was reflected in the reorganization of the Indian computer industry in the 1970s (Grieco 1982). Thus, like the Japanese and NIC cases, Indian sectoral experience indicates the problems inherent in relying too much on government intervention and central planning, as well as the opportunities presented by market-conforming intervention and seizing opportunities.

Adler presents a Brazilian computer industry remarkably similar to the Indian case. Like the Indian Atomic Energy Commission "network" that catalyzed new policies, "ideologically motivated technocrats" or "guerrillas" in Brazil's National Bank for Economic and Social Development (BNDES) forged a successful "pragmatic anti-dependency" program for development of an indigenous computer industry (Adler 1986).

As with East Asian countries, the establishment of a research cluster has been key to India's recent success. India has become a leader in the software industry, and much of this has been located in Bangalore. Many of the policies of the pre-economic liberalization (pre-1991) governments helped foster this industry, which allowed Indian entrepreneurs to take advantage of foreign technology and practice software outsourcing. Bangalore really took off after the liberalization allowed domestic firms to grow more quickly, and permitted more extensive tie-ups with foreign firms. Thus, the role of government was critical in creating Bangalore and other clusters, but private industry largely led the way after liberalization (Dossani 2007).

\section{China}

Any examination of technology development in recent times must deal with the People's Republic of China, which has since 1978 undertaken one of the most ambitious long-term development programs of the postwar period, the "Four Modernizations" and the "Reform and Opening" policies of Deng Xiaoping and his successors. This program fundamentally has been dedicated to reversing the economic stagnation and poverty of the Maoist era. China's early reform goals, states Baum, depended on "expanded economic production made possible by the acquisition of modern high technology" (Baum 1981). The Ten-Year Plan approved in 1978 called for 120 heavy industrial projects, particularly in iron and steel, nonferrous metals, coal, oil and gas, hydroelectric power, railways, and harbors. To finance acquisition of foreign technology, the government rapidly expanded the light industrial sector and its exports, the tourist industry, and energy exports (Baum 1981). 
An edited volume by Baum calls attention to a number of early technology issues affecting China's technological modernization. Fingar discusses China's "maxi-max" strategy involving high risks on technological quick-fixes to secure maximum benefits. Long-term solutions to technical problems, he insists, could be bought "out of the box" from foreign suppliers (Fingar 1981). Dean suggests that the fundamental problem facing Chinese modernization was a lack of institutionalized innovativeness. Chinese leaders usually saw technology as socially neutral, and failed to consider the "socially dynamic" qualities inherent in using new technology (Dean 1981). Lampton says China's Four Modernizations S\&T effort was divided into three separate, vertical hierarchies-the Academy of Science, the national ministries, and institutes of higher education, and that this may create severe problems of coordination (Lampton 1981).

Volti focuses on the 1980s "dilemmas" inherent in technological change within China. Technological development was "at the heart of all $\cdots$ hoped-for changes, for each is predicated on the application of new inputs and techniques," yet development and application of new technology lead to even greater problems. In moving from appropriate to modern technology, China resolved the appropriate versus latest technology dilemma that had bedeviled it since 1949. Technology became intimately connected with social change. By the mid-1980s, the modernization effort had put more students in school, and had brought into question centralized control of technological acquisition, but higher technological levels brought new distributional issues: wage differentials to encourage production, occupational categories, incentives for the highly educated, and a revolution of rising expectations among frustrated youth (Volti 1982). Technological change was a process that had to be tightly controlled if it was not to get out of hand.

Chudnovsky and Nagao draw attention to the unique features of the indigenous Chinese capital goods industry. China was the largest manufacturer of capital goods in the developing world, and entered into advanced design and manufacture like South Korea and Brazil, yet did so under at least a partially socialist economic system. China made "remarkable" progress in a fairly short time in establishing capital goods. Early development of the sector passed through three stages: (1) 1949-1960, initial establishment of the sector based on Soviet models, (2) 1960-1975, reduction of contacts with the rest of the world, and (3) 1976-1988, opening of the economy, particularly as regards technology. The third phase saw heavy importation of technology through licensing and manufacturing agreements, which reached an early peak in 1981. Less noticed were imports of whole plants for production of fertilizers, petrochemicals, and synthetic fibers, most of which were subsequently cancelled (Chudnovsky and Nagao 1984).

The policy process for development of capital goods technology, Chudnovsky and Nagao suggest, differs from capitalist countries. China's centralized planning process called for design departments of central government ministries and some 
key state enterprises to make major decisions concerning both indigenous development and licensing agreements. Design offices of local factories, in turn, had to implement the decisions of the design departments. This process lacked an effective relationship between producers and users of capital goods. R\&D was done through independent research institutes which have contractual relations with enterprises, and research institutes connected with leading state firms. Many factorics also performed their own R\&D on specific problems (Chudnovsky and Nagao 1984). Like Chudnovsky and Nagao, Harding describes Beijing's efforts to create independent $R \& D$ institutions through a competitive system of government grants and research contracts. Such institutions and individuals received financial benefits from R\&D projects, and technology rights were protected under law, though the details took time to work out (Harding 1987).

By 1985, China's modernization program was steaming along, but says Bauer, many industries had not met ambitious goals. In the 1983-1984 period, the Chinese government undertook a number of innovations to boost innovation and productivity, such as breaking up some state enterprises, shifting from simple copying to joint ventures in the aerospace industry, constructing China's first nuclear power plants, and allowing a contract system for work done by research institutes for state firms. Also, some of the economic inequalities predicted by Viotti and others in the 1970 s, especially wage differentials, were acknowledged in government reports (Bauer 1986).

China's technology policy only came into its own from the 1990 s onward. Lampton presents China's recent innovation policy as related to its overall effort to improve human resources. He suggests that Chinese leadership has shown a keen interest in technology, and recently followed a realistic path, for example, focusing on incrementally raising the share of GDP dedicated to R\&D to 2.5 percent by 2020. China has done best by focusing on "architectural innovation," that is, altering the way system parts and components work together, and "incremental innovation," which accepts a dominant technology but improves it in terms of cost, delivery, and performance. China has gradually upgraded its $\mathrm{R} \& \mathrm{D}$ labs and university facilities, and is becoming part of MNC global R\&D networks (Lampton 2008).

Walsh notes that technology still plays a key role in state economic management, and has been a centerpiece in all of the recent Five-Year Plans (Walsh 2005). Naughton shows that China's "technology trajectory" differed slightly from other fast developing countries, in that heavy state spending on $R \& D$ during the 1980 s proved unsustainable, and much of the innovation effort thereafter was undertaken by state-run firms and private industry. China pursued several strategies simultaneously, shifting from the autarchic Maoist "Do It Yourself" approach to a sensible "Buy It" policy in the early 1980s. In the late 1980 s, the government promoted R\&D through a system of competitive grants ("Seed It"), and encouraged spin-offs, most famously with the creation of Legend (later Lenovo) Computers. 
During the 1990s, China opened up to MNC technology investment, and since 1999 the government has replaced its former policy of supporting large firms with encouragement of any enterprises working on advanced technology, including private firms and start-ups (Naughton 2007). Many of the most recent successful private firms have been in IT. Sheff describes some of the more noteworthy IT pioneers, such as venture capitalist Bo Feng entrepreneur Edward Tian (Sheff 2002).

As in other East Asian countries, the creation of an S\&T infrastructure centered on science parks has, since the late 1980s, become the key driver of state technology policy. The Zhongguancun Science Park in Beijing, situated near several state universities with science and engineering programs, was the template for a national program that would establish a smaller such center in every Chinese province. Zhongguancun developed through three phases from the early 1980 s to early in the last decade. In the 1990s, the government began to develop additional areas nearby. IT is the largest industry in the park, but it includes other high technology industries, such as new materials. Several multinationals, such as Motorola, have located facilities there, and the government provides various services, including venture capital. By 2002, there were 12,000 companies, with more than 400,000 workers, producing \$29 billion in revenues in the cluster (Zhao 2007).

What Volti described in 1980 and 1982 in fact happened. China attained remarkable growth over the last twenty-eight years, but along the way has encountered innumerable economic and social problems. These included high inflation, corruption, rising crime, and demands for political participation. Neither Volti nor Baum could have predicted the phenomenal success of China's technology development over the last thirty years.

\section{Tanzania}

The S\&T experience of Tanzania was one of the most successful cases among African countries and fairly typical for newly developing countries in the early post-World War II era, yet the Tanzanian government created a more centralized institutional structure than most developing countries. Only a small amount of research activities occurred during the colonial period, but the government showed a keen interest in developing an S\&T infrastructure even before the union of Tanzania was brought about. The East African Commission Services Organization (EACSO), established in 1967, was the first attempt at a general research organization, and the Tanzania National Scientific Research Council (TNSRC), set up the next year, was the first national research coordination organization. However, it was not until the mid-1980s that the government set out a clear technology policy statement. The Tanzania Cornmission of Science and Technology $(\mathrm{COSTECH})$ in 1985 took over TNSRC's functions, while coordi- 
nating a series of sectoral research advisory commissions and acting as the primary policy formulation body for the Ministry of Science, Technology and Higher Education (MSTHE), which began operations in 1990. COSTECH also coordinates research activities of thirty-eight public research institutions, eight private non-profit institutions, and private sector labs (usually dedicated to single objective research, most often in agriculture or natural resources) (Mukama and Yongolo 2005).

Two articles from Tanzania's period of high growth consider the relationship between technological choice and the goals of economic development. Phillips says that the Tanzanian experience showed how choice of industrial strategy should precede selection of techniques of production, since this helps insure the long-term growth of industry and links technology to the type of output desired. Like many African countries, Tanzanian industrial structure was shaped by its colonial experience, and in the early postwar era consisted of small firms that were largely geared toward the export of primary products and servicing of urban consumer markets. However, from 1967 to 1975. Tanzania nationalized its export sector and established a range of intermediate product industries, such as tires, steel products, chemical fertilizer, and farm equipment. Much of this production was dependent on foreign imports, even where raw materials were available locally, and location of production was skewed toward the cities, even in small-scale production. The percentage of production by large firms steadily increased, as many small-scale operations closed their doors, and large firms suffered from chronic overcapacity. Moreover, external dependence on foreign investment has drained profits out of the country. The fundamental problem, concludes Phillips, was policies that prevented the "formation of domestic linkages and encouraged export processing and import substituting consumer goods," such as lack of integration of intermediate industries with final producers and the virtual absence of engineering production (Philips 1984).

Perkins sees the problem of Tanzanian technology development as a failure to use appropriate technology. In a survey of 300 industrial units, he finds that though the majority of firms use labor-intensive, low unit cost, small-scale techniques, they do not employ the most appropriate technologies, that is, other available techniques are less capital and more labor-intensive. While more appropriate techniques have been used in several Tanzanian industries, most of the "parastatals" (a form of state-owned enterprise) tend to use more capital-intensive techniques than private firms. This was truer for state-created parastatals than nationalized firms. Industries were often chosen to manufacture products for which simpler local substitutes exist. Even the Small Industries Development Organization (SIDO), set up to assist small-scale industries, pushed the same kinds of products and techniques as produced by the large-scale parastatals. Perkins suggests the major reasons for this overall tendency toward capital-intensive production were as follows: factor and product price distortions, lack of information about alternatives, exaggerated risk assessment, monopolistic and oligopolistic 
markets, and the failure to consider labor-intensive techniques. It also reflected dependence on MNCs, poor government planning, "lack of coherent project selection," and inadequate coordination of ministrics (Perkins 1983).

Once more, the notion of appropriate technology runs into severe problems. Perkins's sweeping discussion of the concept, without disaggregating it by industry, could be misleading. While it may make sense to speak of using the most labor-intensive technique available in the shoe-making indusrry, ir would probably be ineffective to use labor-intensive techniques in a capital-intensive industry such as steel. In competitive international industries such as steel, a nascent industry requires the latest techniques, or it would have to settle for less efficient older technology cast off by the advanced industrial countries.

During the 1990s and this decade, Tanzanian technology policy gravitated to two poles. One concerned development of basic technologies to aid rural development. Such items as increased use of ox cultivation which is cheaper than mechanized techniques, and greater utilization of hand and ox carts to reduce time spent carrying water, firewood, and agricultural goods, were highly recommended. Appropriate technology was specified as that which could be "absorbed and integrated into the local economy" (Kopoka 1996). Mcanwhile, there was much discussion among civil society groups about the need for an IT policy, which the government finally issued in 2002. Its principles were universal access, promotion of local content, and public-private-civil society partnership. Policy was to be coordinated by the National Information and Communications Technology Commission (NICTCOM) (Tanzania 2002). Civil society groups are still calling for further opening of IT technology.

\section{Implications of These Cases for Political Economy Literature}

Most analysts who have examined the four cases above fall into the statist camp, that is, most of them see the state taking the lead role in shaping acquisition or indigenous development of technology. They generally see development of the latest technology as a way to leapfrog the developmental process, as stated in the first section. The crucial state role comes across most clearly in the articles on Taiwan and South Korea by Arnold, Choi, Hemmert, and Bae et al., but can also be seen in discussions of China's technology development program from Baum and Viotti to Lampton, Naughton, and Zhao, and analysis of India's computer industry by Grieco, its petrochemical industry by Khanna, and the software industry by Dossani. However, as noted by Desai, Chudnovsky and Nagao, and Dossani, the market remains an important force shaping the direction of technology development. Analysis focusing on East Asian states' management of technological upgrading, especially through targeted programs such as the ones created on research/industrial parks, may provide an effective explanation of the region's success. Tanzania's limited success is perhaps due to its focus 
on more simple technologies, and the overall slowdown of its socialist economy after 1985 .

\section{THEORETICAL IMPLICATIONS IN LIGHT OF DEVELOPING WORLD CASES}

The literature examined here creates a mixed picture of the possibilities of technology development among developing countries. Difficulties encountered by such countries as China and Tanzania, the mixed record of India in spite of its ambitious efforts, and the rarity and uniqueness of the East Asian NICs point out the perilousness of technology development. Technology transfer comes with significant political and economic strings attached, and entails import of culture and psychology along with know-how or techniques. Indigenous technological development, by contrast, is even harder to come by, as the obstacles to development are often daunting, except for very large economies, such as China, India, and Brazil, or relatively well-off ones, such as the East Asian NICs.

Many analysts highlight the opportunities that technology can provide. The bargaining school believes states can deal effectively over time with MNCs, the chief conduit of foreign technology for developing nations. The statist and liberal economic schools, the most strongly represented in the literature, place differing emphases on the critical roles of states and markets. Statists see the state as the lead actor in the transfer or indigenous development of technology, and call attention not only to the clear successes (Taiwan and South Korea), but the mixed successes (India, Brazil, China, and Tanzania) as indications of state ability to guide the technological developmental process. Accordingly, most statists see technology development as first and foremost a political process. They differ only over the usefulness of appropriate technology, though most suggest that obtaining the latest technology is critical for overall economic development. Indeed, the state has been the key to technology development in all cases of successful development: the pre-World War II developers (Great Britain, the United States, the Soviet Union, and Japan), a postwar redeveloper (Japan), and the most successful postwar developers (South Korea, Taiwan, India,

Brazil, and China). The state can play a shadow role, providing tax and tariff assistance or military procurement in the United States, but it is usually at the forefront of the process, at least in the initial stages of development. Arnold, for instance, clearly shows strong states at work.

Economic liberals focus on market forces as determining technical development and innovation. Smith and Barfield, for instance, describe three major approaches used by economists to assess the economic impact of innovation on the U.S. economy: (1) the relationship between $R \& D$ inputs and economic outcomes 
in value added, net profits, output, and macroeconomic growth rates, (2) estimation of the contribution of technical change to economic growth or development of specific industries, and (3) case studies of the history of specific products or industrial processes (Smith and Barfield 1996). In spite a strong state role, most of the successful developers have undertaken technology development in conformity with the development of a market economy. This indicates that the role of government, while crucial, should not be so interventionist as to impede market forces. Here the most successful cases have been the United States, which allowed a relatively free market, and Japan, which used regulatory (or neo-mercantilistic) but basically market-conforming schemes. China presents a mixed case, among the strongest economic performance over the past three decades, partly as a result of liberalizing both its overall economy and its technology acquisition process, its economy has produced major imbalances in part because its success as a mass exporter has made it dependent on continued economic growth in the advanced economies.

The Chinese experience also shows the importance of being aware of the obstacles in the path of either technology transfer or indigenous development, as well as the social problems engendered by fast technological development. When a country imports technology, for instance, it imports a socio-economic package along with it. This package includes new managerial attitudes, socioeconomic inequalities, and challenges to traditional ways of doing things. China's leadership went from imaginative reform to conservative crackdown and back to accelerated reform and deepening during the Deng period. The problems inherent in the Chinese development program were plain for analysts to see as early as 1978 , as the Baum and Viotti works testify, but in the IT and automotive industries China began to find its technological footing from the late 1990s onward.

Besides choosing the right technology and being aware of the socioeconomic pitfalls, the most important task for developers of technology is to focus indigenous development of desired technology. For most of the successful Asian cases, that has meant creating successful science/research parks or high technology clusters, from the tightly focused, government-led Hsinchu Science-based Industrial Park to the more industry-led Bangalore software cluster. China's Zhongguancun area has been a less consciously designed, but effective template for public-private cooperation throughout the country.

The technology development literature easily yields general conclusions, but little in the way of specific policy prescriptions. This is particularly ironic in a literature which seeks to describe cutting-edge processes. There are at least six major deficiencies in the literature. First, its approach is far too traditional, that is, primarily involving simple description with lists of conditions an author feels necessary for a particular policy outcome, providing spotty analysis and almost no predictive capability. Concepts are stated with little discussion of why they are necessary or superior to other approaches. These mulcitudinous 
lists might serve as indicators for empirical studies, but have so far not been used for this purpose.

How can traditional studies come to grips with something as complicated as the fast-developing communications technologies, what Sauvant calls "transborder data flows"? Aronson describes three technology trends that have been at the core of economic globalization: the increase in data transmission, the ubiquity of the internet and worldwide web, and the creation of wireless networks. Only a few countries, such as China, Brazil, Canada, France, Japan, and Sweden, have formulated policies to deal with these issues (Sauvant 1983; Aronson 2005).

Morita-Lou provides a checklist of possible indicators that could be used to measure technology development, such as funding, manpower, patents, S\&T literature (e.g., paper and citation counts, education and training), "dependency" on foreign S\&T information indicators (e.g., number of libraries or journals), and "linkage indicators," including percent of scientists in industry, patent citations, and licensing royalties. Even though her contribution is two decades old, it provides a useful measurement set (Morita-Lou 1985). An equally effective approach is Hemmert's dissection of the Korean national innovation system (Hemmert 2007).

Second, the only empirical studies examined here are case studies. Of course, case studies can be useful for getting a snapshot of the political process of a particular country and for doing comparative analysis. As with the general studies above, they are far more descriptive than analycical. These cases can indicate important factors to watch for in the technology development process, such as the leading role of the state in South Korea or the impact of technology on the overall pattern of economic development in China, but these constitute only one aspect of the study of technology development. More useful may be the Keller and Samuels cross-case comparison of technological innovation after the Asian Financial Crisis. They suggest that Asian governments responded to the crisis not by embracing international liberal norms, but supporting innovations that made their industries more competitive both within the region and the global economy (Keller and Samuels 2003).

Third, economics theory faces severe limitations in dealing with conditions in developing countries (Fransman 1985). Because development of technology is a matter of the political or policy process as much as economic cycles, it is more properly a subject for political economy. Various countries have sought alternatives to capital-intensive, energy-intensive technology that they believe has not worked (Fransman 1985). It may be necessary to develop radically different approaches to technical change. Focusing on incremental change has the advantage of bringing analysis of developed and developing countries closer together, since the approach needed to analyze incremental changes would be roughly the same in both areas. Furthermore, the Japanese example may be useful in showing how incremental change and diffusion processes work (Fransman 
1985).

Fourth, most of the concepts about technology development are either ill-defined or cover such a variety of phenomena that their usefulness is questionable. Fransman states that there is as yet no "rigorous theory of technical change" and therefore inter-firm, international, and "inter-temporal" differences in technical change cannot be explained (Fransman 1985). As an ideological construct, appropriate technology has limited theoretical applicability. Unless useful indicators can be constructed, it should be studied more as a social and international movement than as an analytical concept. Even more hard-core concepts such as technology transfer are poorly defined. With better defined concepts, researchers could apply indicators that would allow empirical observation of transfer.

Also needed are better theories of the state's role in technical change. For instance, many current theories base their analysis on assumptions of rational choice, that is, governments make choices weighing benefits versus costs, and uncertainty in "relatively long-time horizons." Policy is more often than not a response to interests and political pressure, and may result from clashing objectives of groups within a government, or from "underlying" socioeconomic processes. If the state responds only to such underlying forces, is it really distinct from the society? Leftist theories of development and the state gain by discarding assumptions of rationality, but lose by failing to specify which actors are dominant in terms of policy making (Fransman 1985). Perhaps even more important than poor understanding of the state is the lack of any general understanding of the relationship between a science and technology community and the political process. The growth of information technology, observe Mansell and Silverstone, alters the relationship between peoples and governments, and produce considerable impacts on industry, government operations, and everyday life (Mansell and Silverstone 1996).

Fifth, there is an unfortunate tendency toward overgeneralization of conditions pertaining in the developing world, and therefore oversimplification of the process of technology development. Developing countries manifest great diversity, and fall into at least three or four main categories, and perhaps many more specific categories. When one considers why a nation's leadership wants technology and what it does with that technology, it is also important to disaggregate the factors behind the technology development process (Chiriyankandath 2008). This means dealing with a series of critical questions, such as (1) What kind of country is it? Is it an industrializing economy (e.g., a NIE), which has substantial financial resources, a country-continent such as India with ample manpower and a large economy, an exporter of primary products, or a resource-poor, money-poor country? (2) What kind of technologies does it seek to import or develop locally, and for what industries? (3) Who controls the process of technological acquisition: the private sector, government ministries, or state-run firms? (4) Finally, is there a guiding ideology concerning economic development and technol- 
ogy in the society or government, and what are the objectives of technology development in the society? Such questions can assist design of cross-country surveys to make more general conclusions about the technology process.

Sixth, there needs to be more attention to what Dahlberg calls the "technological ethic." Most technology absorbed by developing countries is based on "Westernbiased" assumptions. This concern relates to technology adaptation as a socioeconomic package, mentioned before, but includes a broader notion of the plulosuphy of science. This raises a number of questions, such as people's relationship to the environment (Dahlberg 1983). Is appropriate technology really a response to the Western'scientific and technical ethic? More recently, Forester and Morrison show, the most prominent ethical concerns have centered on misuse and abuse of computers. Social problems include computer crime, computer security, hacking and creation of viruses, storage and misuse of private data, and lack of computer privacy in the workplace (Johnson 2008). Perhaps the ultimate issues here are as much philosophical and sociological as political and economic.

Noting these deficiencies in the literature, what are the most urgent tasks facing research on the development of technology in the developing world? To begin with, both concepts and types of nations must be better defined. As part of this effort, the exact role of technology development in overall development needs to be pinned down more precisely. Is technology the key factor behind development? Can it be separated from other factors in development? Next, studies must consider both political and economic factors in technological acquisition. Then, universal indicators for technology development should be listed and tested in empirical, cross-country studies. Also, there should be more comparative analysis of individual development cases, perhaps with reference to existing case studies. Finally, future case studies must more rigorously analyze the technology development process in each country.

\section{CONCLUSION}

Developing countries have devised various strategies to develop a technology capacity. One of the most effective has been state-led creation of technology/research parks or technology clusters, from the focused HSIP in Taiwan to the more diffuse Bangalore software cluster in India. The study addressed three areas: (1) technology development theory, (2) the nature of indigenous technology development, and (3) leading cases of technology development, that is, the Newly Industrialized Countries (NICs) of South Korea and Taiwan, as well as India, and China. Tanzania was presented as a contrasting case of more limited technological development.

Analysts have most often employed three general approaches to study of technology development: the state-centric, dependency, and bargaining approaches. These 
three have loose connections to larger political science approaches: statism to interdependence, dependency to other leftist approaches, and bargaining to liberalism. The statist approach dominates the literature on technology transfer, indigenous development, and most specific cases of development. Each of these schools has made limited contributions to empirical literature on indigenous technology development. A number of concepts remain undeveloped, especially appropiriare technology, and analysts have not as yet adequately specified indicators for most of the concepts currently used. Most of the study of technology to date has taken a distinctly traditional approach heavy in case studies and qualitative analysis, or has failed to combine political economic theory and real world politics in a productive way. The current body of literature on technology development should be taken as a starting point for more complete analysis of technology development in developing country.

\section{REFERENCES}

Adler, E. 1986. Ideological guerrillas' and the quest for technological autonomy: Brazil's domestic computer industry. International Organization 40(3): 686-704.

Aronson, J. D. 2005. Causes and consequences of the communications and internet revolution, $3^{\text {ril }}$ ed. In The Globalization of World Politics, eds. John Baylis and Steve Smith, 621-643. Oxford: Oxford University Press.

Arnold, W. 1988. Science and Technology Development in Taiwan and South Korea. Asian Survey 28(4): 437-449.

Bae, Z.-T., J.-W. Bae, J.-G. Kim, K. B. Lee, S.-M. Suh, and S. O. Park. 2007. The Tale of Two Valleys: Daeduk and Teheran. In Making IT: The Rise of Asia in High Tech, eds. Henry S. Rowen, Marguerite Gong Hancock, and William F. Mille, 175-191. Stanford, CA: Stanford University Press.

Bauer, E. E. 1986. China Takes Off: Technology Transfer and Modernization. Seattle: University of Washington Press.

Baum, R. 1981. Introduction. In China's Four Modernizations: The New Technological Revolution, ed. Richard Baum, 1-4. Boulder, CO: Westview Press.

Berger, S. and R. K. Lester. 2005. Globalization and the Future of the Taiwan Miracle. In Global Taiwan: Building Competitive Strengths in a New International Economy, eds. Suzanne Berger and Richard Lester, 3-10. Armonk, NY: M. E. Sharpe.

Carter, R. 2011. Introduction. $4^{\text {th }}$ ed. In Contemporary Cases in U.S. Foreign Policy, ed. Ralph Carter, 1-10. Washington, D.C.: CQ Press.

Choi, H. S. 1986. Technology Development in Developing Countries. Tokyo: Asian Productivity Center.

Chiriyankandath, J. 2008. Colonialism and Post-Colonial Development. In Politics 
in the Developing World, eds. Peter Burnell and Vicky Randall, 35-50. Oxford: Oxford University Press.

Chudnovsky, D. and M. Nagao. 1984. Capital Goods Production in the Third World: An Economic Study of Technology Acquisition. London: Frances Pinter Publishers.

Clemens, W. 2004. Dynamics of International Relations: Conflict and Mutual Gain in an Era of Globa! Interdependence. $2^{\text {nd }}$ ed. Lanham, MD: Rowman and Littlefield.

Dahlberg, K. A. 1973. The Technological Ethic and the Spirit of International Relations. International Studies Quarterly 17(1): 84-85.

Dean, G. C. 1981. A Note on Recent Policy Changes. In China's Four Modernizations: The New Technological Revolution, ed. Richard Baum, 103-118. Boulder, CO: Westview Press.

Desai, A. V. 1988. Technology Acquisition and Application: Interpretations of the Indian Experience. In The Indian Economy: Recent Development and Future Prospects, eds. Robert E. B. Lucas and Gustav F. Papanek, 163-177. Boulder, CO: Westview Press.

Dossani, R. 2007. Entrepreneurship: The True Story behind Indian IT. In Making IT: The Rise of Asia in High Tech, eds. Henry S. Rowen, Marguerite Gong Hancock, and William F. Miller, 221-254. Stanford, CA: Stanford University Press.

Edwards. C. 1992. Industrialization in South Korea. In Industrialization and Development, eds. Tom Hewitt and David Wield. Oxford: Oxford University Press.

Fingar, T. 1981. Recent Policy Trends in Industrial Science. In China's Four Modernizations: The New Technological Revolution, ed. Richard Baum, 61-100. Boulder, CO: Westview Press.

Forester, T. and P. Morrison. 1981. Computer Ethics. In Technology and Man's Future, ed. Albert H. Teich, 263-269. New York: St. Martin's Press.

Fransman, M. 1985. Conceptualising Technical Change in the Third World in the 1980s: An Interpretive Survey. The Journal of Development Studies 21(4): 634-638.

Freeman, C. and L. Soete. 1999. The Economics of Industrial Innovation. $3^{\text {rd }}$ ed. Cambridge, MA: The MIT Press.

Fuller, D. B. 2005. Moving Along the Electronics Value Chain: Taiwan in the Global Economy. In Global Taiwan: Building Competitive Strengths in a New International Economy, eds. Suzanne Berger and Richard K. Lester, 137-140. Armonk, NY: M. E. Sharpe.

Greven, M. T. 1982. Dependent Reproduction and the Role of Science in Cultural Alienation. International Political Science Review 3(3): 277-280.

Grieco, J. M. 1982. Between dependency and autonomy: India's experience with the international computer industry. International Organization 36(3): 612-632. 
Gupta, V, and A. Reisman. 2009. India's Economic Development: The Role of Institutionalized Technology Transfer. Social Science Research Network. Accessed January 13, 2009. http:// papers.ssrn.com/sol3/papers.cfm?abstract id $=721644$.

Harding, H. 1987. China's Second Revolution: Reform After Mao. Washington: The Brookings Institution.

Hemmert, M. 2007. The Korean Innovation System: From Industrial Catch-Up to Technological Leadership? In Innovation and Technology in Korea: Challenges of a Newly Advanced Economy, eds. Jorg Mahlich and Werner Pascha, 11-31. Vienna: Physica-Verlag.

Holsti, K. J. 1972. International Politics: A Framework for Analysis. 2nd ed. Englewood Cliffs, NJ: Prentice-Hall, Inc.

Johnson, D. G. 2008. Computer Ethics. In Technology and the Future, ed. Albert H. Teich, 283-296. New York: Wadsworth Publishing.

James, J. and H. Khan. 1998. Technological Systems and Development. New York: St. Martin's Press.

Kegley, C. W. Jr. and E. R. Witckopf. 1997. World Politics: Trend and Transformation. $6^{\text {th }}$ ed. New York: St. Martin's Press.

Keller, W. W. and R. J. Samuels. 2003. Innovation and the Asian Economies. In Crisis and Innovation in Asian Technology, eds. W. W. Keller and R. J. Samuels, 1-22. Cambridge: Cambridge University Press.

Khanna, S. 1984. Transnational Corporations and Technology Transfer: Contours of Dependence in Indian Perrochemical Industry. Economic and Political Weekly, XIX(31-33): $1327-1338$.

Kopoka, P. A. 1996. Technology and Poverty Reduction in Tanzania. From Proceedings of a Workshop on Poverty Alleviation at Sokoine University of Agriculture, Morogoro, Tanazania, 3-17. Accessed January 19, 2009. http:// www. fuc.org/esap/DAR/DAR11/General/kapoka7.pdf.

Lampton, D. M. 1981. Commentary on the Institutional Structure for R\&D. In China's Four Modernizations: The New Technological Revolution, ed. Richard Baum, 128-150. Boulder, CO: Westview Press.

Malhotra, R. and J. Patel. 2003. History of Indian Science and Technology: Overview of the 20 Volume Series, 1-12. Accessed February 11, 2011. http:// www.indianscience.org.

Mansell, R. and R. Silverstone. 1996. Introduction. In Communication by Design: The Politics of Information and Communication Technologies, eds. Robin Mansell and Roger Silverstone, 1-12. Oxford: Oxford University Press.

Mingst, K. 1999. Essentials of International Relations. New York: W. W. Norton and $\mathrm{Co}$.

Morita-Lou, H. 1985. Report on the Measurement of the Impact of Science and Technology on Development Objectives. In Science and Technology Indicators for Development, ed. Hiroko Morita-Lou, 17-19. Boulder, CO: 
Westriew Press.

Mukama, B. C. and C. S. Yongolo. 2005. Development of S\&T System and Experience of Tanzania on S\&T Data Collection, presentation at the Regional Workshop on Science and Technology Statistics, in Entebbe, Uganda, 5-16. Accessed January 16, 2009. http://www. uis.unesco.org/TEMPLATE/pdf/S\&T/ Workshops/Entebbe/Country\%20reports/S\&T_092005_3.pdf.

Naughton, B. 2007. The Chinese Economy: Transitions and Growth. Cambridge, MA: MIT Press.

Padelford, N. J., G. A. Lincoln, and L. D. Olvey. 1976. The Dynamics of International Politics. New York: MacMillan Publishing Co., Inc.

Papp, D. S. 1997. Contemporary International Relations: Frameworks for Understanding. $5^{\text {th }}$ ed. Boston: Allyn and Bacon.

Perkins, F. C. 1983. Technology Choice, Industrialisation and Development Experiences in Tanzania. The Journal of Detelopment Studies 19(2): 213-241.

Philippart. A. 1982. Transfers: Decision-Making Complexity and Influence on Decision-Making Powers. International Political Science Review 3(3): 273-274.

Phillips, D. A. 1984. Choice of Technology and Industrial Transformation: The Gise of the United Republic of Tanzania, In Technology Policy and Development:

a Third World Perspective, ed. Pradip K. Ghosh, 325-338. Westport, CT: Greenwood Press.

Rosenberg, N. 1994. Exploring the Black Box: Technology, economics, and history. Cambridge, UK: Cambridge University Press.

Rowen, H. S. 2007. An Overview. In Making IT: The Rise of Asia in High Tech, eds. Henry S. Rowen, Marguerite Gong Hancock, and William F. Miller. Stanford, CA: Stanford University Press.

Sauvant, K. P. 1983. Transborder data flows and the developing countries. International Organization 37(2): 368-371.

Sheff, D. 2002. China Dawn: The Story of a Technology and Business Revolution. New York: HarperBusiness.

Shih, C., K. Wang, and Y.-L. Wei. 2007. Hsinchu, Taiwan: Asia's Pioneering High-Tech Park. In Making IT: The Rise of Asia in High Tech, eds. Henry S. Rowen, Marguerite Gong Hancock, and William F. Miller, 101-120. Stanford, CA: Stanford University Press.

Smith, B. L. R. and C. E. Barfield. 1996. Contributions of Research and Technical Advance to the Economy. In Technology, R\&D, and the Economy, eds. Bruce L. R. Smith and Claude E. Barfield, 1-6. Washington: The Brookings Institution. Tanzania Ministry of Communications and Transport. 2002. National ICT Policy of Tanzania, First Order Draft, 29-35. Accessed January 19, 2009. hetp:/l www. ethinktanktz.org/secretariat/DocArchive/zerothorder.pdf.

Todaro, M. P. 2000. Economic Development. $7^{\text {th }}$ ed. Reading, MA: AddisonWesley.

Tuma, E. H. 1987. Technology Transfer and Economic Development: Lessons 
of History. The Journal of Developing Areas 21(4): 1-16.

Volti, R. 1982. Technology, Politics, and Society in China. Boulder, CO: Westview Press.

Walsh, K. A. 2005. Testimony Before the U.S.-China Economic and Security Review Commission on "China's High-Technology Development," 1-10. Accessed November 2, 2011. http://www.uscc.gov/hearings/2005hearings/written testimonies/05_21_22wrts/walsh_kathlecn_wrts.pulf.

Williams, R. 1984. The International Political Economy of Technology. In Paths to International Political Economy, ed. Susan Strange. London: Allen and Unwin, Ltd.

United Nations Economic and Social Commission for Asia and the Pacific. India's Experience in Promoting Business and Technology Incubation, 157-168. Accessed January 13, 2009. http:// www. unescap.org/tid/publication/indpub2323 part2ivD.pdf.

Zhao, M. 2007. Zhongguancun: China's Pioneering High-Tech Cluster. In Making IT: The Rise of Asia in High Tech, eds. Henry Rowen, Marguerite Gong Hancock, and William F. Miller, 197-219. Stanford, CA: Stanford University Press. 